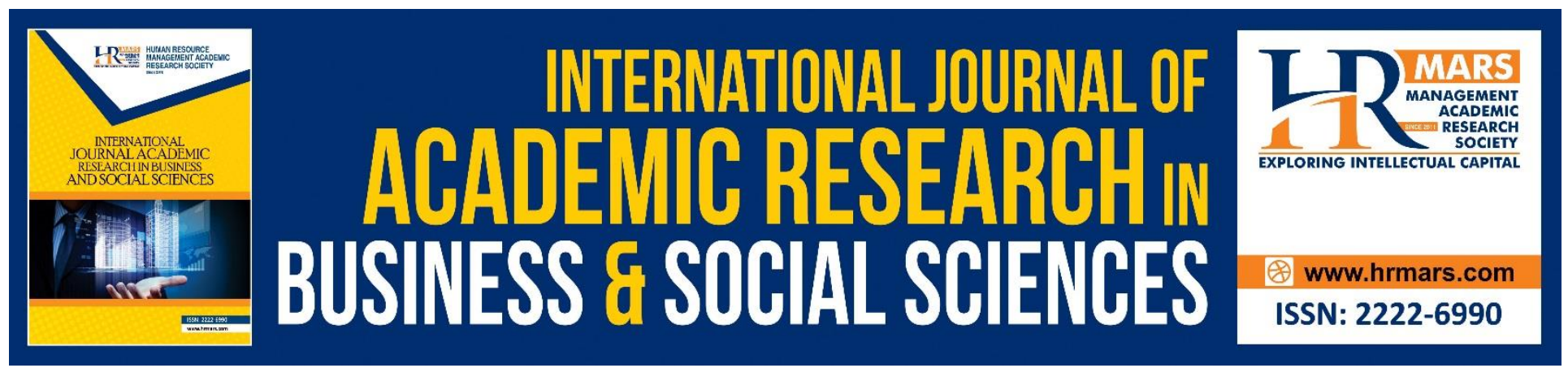

\title{
The Effect of Public Service Motivation and Job Satisfaction on Public Officers' Performance through Commitment
}

Ricky Adi Putranto, Eka Setiajatnika, Indra Fahmi

To Link this Article: http://dx.doi.org/10.6007/IJARBSS/v8-i12/5247

DOI: $10.6007 /$ IJARBSS/v8-i12/5247

Received: 02 Nov 2018, Revised: 13 Dec 2018, Accepted: 21 Dec 2018

Published Online: 28 Dec 2018

In-Text Citation: (Putranto, Setiajatnika, \& Fahmi, 2018)v

To Cite this Article: Putranto, R. A., Setiajatnika, E., \& Fahmi, I. (2018). The Effect of Public Service Motivation and Job Satisfaction on Public Officers' Performance through Commitment. International Journal of Academic Research in Business and Social Sciences, 8(12), 1422-1435.

Copyright: (C) 2018 The Author(s)

Published by Human Resource Management Academic Research Society (www.hrmars.com)

This article is published under the Creative Commons Attribution (CC BY 4.0) license. Anyone may reproduce, distribute, translate and create derivative works of this article (for both commercial and non-commercial purposes), subject to full attribution to the original publication and authors. The full terms of this license may be seen

at: http://creativecommons.org/licences/by/4.0/legalcode

Vol. 8, No. 12, 2018, Pg. 1422 - 1435

http://hrmars.com/index.php/pages/detail/IJARBSS

JOURNAL HOMEPAGE

Full Terms \& Conditions of access and use can be found at http://hrmars.com/index.php/pages/detail/publication-ethics 


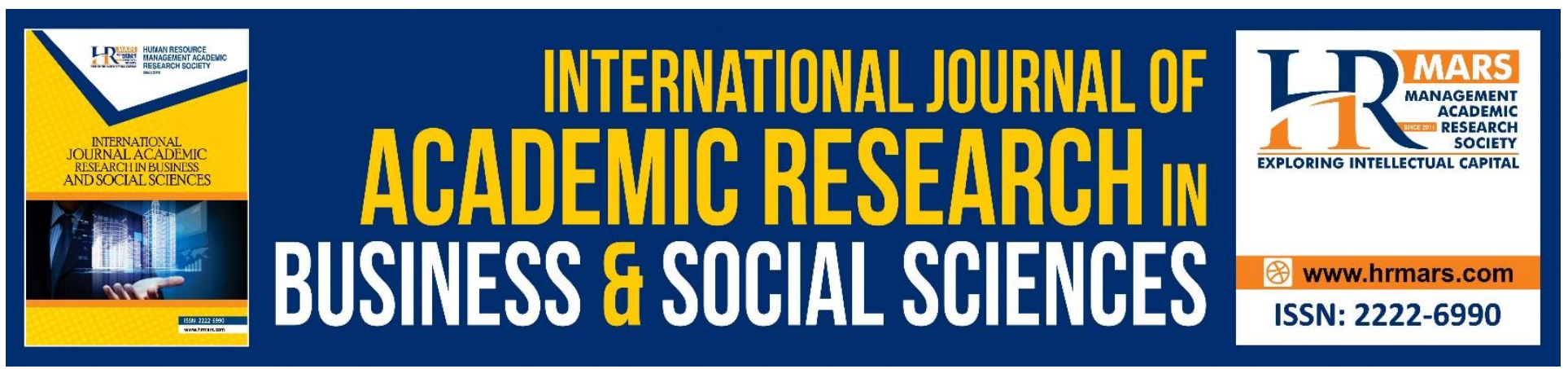

\title{
The Effect of Public Service Motivation and Job Satisfaction on Public Officers' Performance through Commitment
}

\author{
Ricky Adi Putranto1), Eka Setiajatnika²), Indra Fahmi2) \\ ${ }^{1}$ School of Administration, National Agency for State Administration, Bandung, Indonesia \\ ${ }^{2}$ The Indonesian Cooperative Management Institute (IKOPIN), Jatinangor, Sumedang, Indonesia
}

Abstract: The purpose of this study is to examine factors of individual attitudes (public service motivation, job satisfaction, and organizational commitment) in affecting public officers' performance. Building an integrative framework model from all three constructs then testing it on public officers will provide a more comprehensive and dynamic understanding of the pattern of public officers' performance in public institutions. Public officers who work at National State Administration Institution located in Jakarta, Bandung, and Makassar (92 employees come from STIA LAN Jakarta, 86 employees come from STIA LAN Bandung, and 75 employees come from STIA LAN Makassar) which amounted to 253 people were taken as respondents in this study. The samples collected were 221 people from 253 employees of STIA LAN. The data collected from the questionnaire instrument were distributed and analyzed by using structural model based on Partial Least Square. Findings of this study revealed that two of the five hypotheses were not supported, those are the effect of public service motivation on organizational commitment and job satisfaction on employee performance. The research findings revealed an emphasis on the important role of mediating organizational commitment in the effect of job satisfaction on employee performance. The most important practical implication is to make a satisfied employee improve their performance; they should be more committed to the organization.

Keywords: Public Service Motivation, Job Satisfaction, Organizational Commitment, Public Officer Performance.

\section{Introduction}

The central idea of performance management reform is that results-based accountability must be accompanied by quality improvements from employees. As a result, it will give flexibility to government organizations to design performance-oriented changes. Emphasis on improving performance in the public sector has led to the development of systems to measure performance in local government. In a strategic perspective, Jackson (1993) explained that evaluation of government 
activities is essential in democracy, because the government (at any level, central, regional, institution and or institution) must be responsible and accountable to the people and other stakeholders. The direction of the performance management system has been widely debated to influence organizational behavior and performance in several ways. However, superior organizational performance is achieved through individuals within it (Mostafa, Gould-Williams, and Bottomley, 2015). The main objective for many public sector performance measurement schemes - and perhaps the most common is to make public service provision more transparent. It can be done through helping the executive and legislature to ensure compliance by asking managers to be accountable to official performance goals and standards. Continuous processes involving goal setting and performance feedback also becomes signal to administrators and employees about the principal objectives of the current public organization and how to prioritize them among a number of employees. The achievement of high individual performance requires an increase in optimal work effort to be able to utilize the potential of human resources in order to achieve organizational goals, so that it will contribute positively to the development of the organization (Robbins and Judge, 2008). Employee performance is one form of employee behaviors related to his work (Shore and Martin, 1989) which is important to be assessed and measured (Viswesvaran, 2001), and has important psychological elements as a form of development for the organization (Sonnetag and Frese, 2002).

Some previous literature has discussed the relationship between factors that affect employee performance. At the individual level, employee performance can be influenced by job satisfaction (Shore and Martin, 1989; Ostroff, 1992; Saari and Judge, 2004), motivation (Orpen, 1997; Gagne and Deci, 2005), and organizational commitment (Mathieu and Zajac, 1990; Suliman and Iles, 2000; Suliman, 2002; and Riketta, 2002). These three things (satisfaction, motivation, and commitment) can be interrelated with one another in explaining employee performance. The pattern of relationships and interactions between these three things can reveal some interesting things in the study of human resources in the organization.

Motivation can encourage employees to be able to improve their performance. Individuals who work as civil servants who have been motivated in public service needs will be more productive and committed. In public organizations, the motivation of public services (public service motivation or PSM) is important in influencing the performance of civil servants (Alonso and Lewis, 2001; Camilleri and Heijden 2007; Leisink and Steijn, 2009). In the end, public service motivation can be expected to lead to the desired outcomes of employees and organizations.

The empirical results of Alonso and Lewis (2001), based on Perry and Wise (1990) on the needs of the government in reframing motivational questions in public sector employees, have examined the linkages between PSM and employee performance in the federal sector in the United States. Perry and Wise (1990) have a stronger public service motivation than private sector employees but the government can use these ethics to increase productivity. Camilleri and Heijden (2007) stated that well-managed public organizations tend to produce higher levels commitments from of employees; hence this condition leads to higher levels of PSM and performance. These results are reinforced by the empirical findings of the research of Leisink and Steijn, (2009) that there is a correspondence 
INTERNATIONAL JOURNAL OF ACADEMIC RESEARCH IN BUSINESS AND SOCIAL SCIENCES Vol. 8, No. 12, Dec, 2018, E-ISSN: 2222-6990 @ 2018 HRMARS

between the relationship of public service motivation and the willingness to exert effort and performance in the work shown by individuals. Therefore, there is a need to overcome these problems to be applied in the administrative system not only for better bureaucratic efficiency but also to get employees who are motivated and satisfied and more committed to their organization. As employees, perceptions of organizational rules and procedures have real and direct consequences on individual performance.

The important link between public service motivation for employee performance was reinforced by Taylor (2008), Belle (2012), Cheng (2015). An additional argument from the Leisink and Steijn (2009) study is to support the view that public service motivation can increase with age (or more strictly that older public sector workers tend to demonstrate these motivations) and levels of education. This fact shows that public service motivation can decrease over time. Therefore, it is important for the management of public organizations to continue to manage it as a form of effectiveness in managing their human resources.

\section{Literature Review and Hypotheses Development}

Alonso and Lewis (2001) examined the public service motivation model that is associated with performance and merit. There is important evidence that PSM positively affects value and performance appraisal. There is also a clearer evidence that employees are expected to receive material rewards for outstanding performance which is indicated by higher performance scores and ratings. There is no evidence related to the relationship between material rewards and performance issues with employees those who have high PSM. This shows that public service motivation is closely related to individual performance.

Camilleri and Heijden (2007) examined the mediating role of public service motivation and commitment in the effect of antecedents on employee performance. The results showed that employee perceptions of how well the organization is managed tend to result in higher commitment, leading to higher levels of PSM and performance. The findings also showed that job characteristics have a direct impact on organizational commitment and PSM but the effect is not very significant on performance. Leisink and Steijn (2009) examined the extent to which public service motivation among employees in various segments of the public sector in the Netherlands, as well as whether PSM was in line with the relationship between public service motivation and commitment, and the willingness to exert effort and work performance. The results showed that employees in various segments of the public sector in the Netherlands had high public service motivation and that the difference between employees in various small segments. This applies to PSM, and also for two dimensions specifically examined, namely the attractiveness of public policy making and commitment to the public interest. In the context of civil servants, the findings of Akbar (2014) supported that motivation does not mean that it is important to drive performance. While Suwardi and Utomo (2011), Komara and Nelliawati (2014), and Harlie (2012) revealed that even though they were considered meaningful, the motivation of civil servants was not the most important thing in influencing the performance displayed.

In addition to motivation, Ajzen (2011) has confirmed the pattern of satisfaction and performance relationships through the theory of planned behavior. Although it could not be denied the fact that 
in the relationship between job satisfaction and employee performance, satisfaction is found to be insignificant (Hidayat and Ferdiansyah, 2011; Dinc and Plakalovic, 2016). Contrary to some findings, previous studies have convinced that job satisfaction is important as a determinant of the performance of civil servants (Akbar, 2014; Komara and Nelliawati, 2014; and Suwardi and Utomo, 2011).

Civil servants can argue that individuals with different value systems or personalities will exhibit different types of commitments, and therefore it is not wise to focus on only one measure of commitment. However, the relative homogeneity of the respondents, related to seniority and job characteristics, can allow assumptions to be made for most people who will be able to find alternative jobs, even if they feel satisfaction at work (Mouloud, Bougherra, and Samir, 2016; Dinc and Plakalovic, 2016).

Employee commitment to the organization has become an important area of research in the study of organizational behavior for decades (Riketta, 2002; Suliman, 2002; Susanty and Miradipta, 2013). Previous studies have examined the relationship between commitment and individual characteristics, for example, perceived competence, age, gender, age, marital status, education, and salary (Mathieu and Zajac, 1990). However, recently Dinc and Plakalovic (2016) and Rajagukguk (2016) revealed the findings that organizational commitment does not mean important to employee performance. This is one of the research gaps on which this research is based.

Some previous empirical results supported the important linear relationship between motivation for organizational commitment (Ranihusna, 2010; Gondokusumo and Sutanto, 2015; Rahmawati et al., 2015). The general empirical results of the relationship pattern conclude a significant positive effect, which means that the higher the employee's work motivation can increase employee organizational commitment. There are different findings from Hayati and Chaniago (2012); where it has been revealed that motivation does not mean important to employee organizational commitment.

In some previous research findings (eg Crewson, 1997; and Christensen and Wright, 2011) for the context of public management according to Potipiroon and Ford (2017), the motivation of public services generally leads to an increase in organizational commitment from employees. Although this is also accompanied by an opinion which states that the relationship turned out to be more complex than the general assumptions which were previously formed. Above all these things, the perspective formed is that individuals with high public service motivation will bring someone to a tendency to commit more to the organization. This is based on the role of intrinsic motivation (as well as the public service motivation), which captures the extent to which a person finds interest and comfort in work and he is motivated to do work with more effort without reward. These conditions can lead to the attitude of employees on work or organization.

Based on this description and the empirical and theoretical study in the previous section, the first hypothesis proposed in this study is as follows:

H1: Public Service Motivation has important effect in Increasing Employee Organizational Commitment

Previous experts have stated in some research that if someone has fulfilled all the needs and desires of the organization, automatically with full of awareness, they will increase the level of his commitment (Ranihusna, 2010; Altinoz et al., 2012; Yucel and Bektas, 2012). In general, the empirical 
findings strongly support the premise that the increased of job satisfaction felt by employees will further encourage these employees to be more committed to the organization or institution where they work (Gondokusumo and Sutanto, 2015; Mouloud et al., 2016; Dinc and Plakalovic, 2016; and Oktariani et.al., 2017). From some of the descriptions above, it can be concluded that job satisfaction has a direct positive effect on the level of commitment that individuals feel towards their organization. This means that the higher employee satisfaction on his job will further increase his organizational commitment. Employees who fulfilled their work satisfaction can be interpreted that their organizational commitment is very high and tends to survive in the organization. While dissatisfied employees will choose out of the organization and look for alternative work that is more satisfying. Based on this description and the empirical and theoretical studies in the previous section, the second hypothesis proposed in this study is as follows:

H2: Job Satisfaction has important effect in Increasing Employee Organizational Commitment

Previous researchers have tended to carve out aspects of work motivation and job satisfaction into several detailed elements, which may have broken down the convergence of the effects of these factors on performance. Although satisfaction is closely related to performance, it is not different from the motivation which is assumed to have an important impact on the work that someone shows. Several previous empirical results supported an important linear correlation between motivation for employee performance (Hidayat and Ferdiansyah, 2011; Subakti, 2013; Prabowo and Lestari, 2013; Rahayu, 2014), where the general results of the relationship conclude the effect is significantly positive, which means that the higher the employee's work motivation will improve employee performance. But on the other hand, there are several generalized results which are different, where it is found that motivation does not mean important to employee performance (Hayati and Chaniago, 2012; Dharmanegara et.al., 2016). These different results show the dynamics of the relationship between motivational and performance variables, but do not weaken general generalizations that motivation has an important effect on employee performance. In a theoretical perspective, motivation is still seen to have important impact on the performance of individuals within the organization.

Based on this description and the empirical and theoretical studies in the previous section, the third hypothesis proposed in this study is as follows:

H3: Public service motivationhas an important effect to improve public officer performance 
Employees who get job satisfaction will do the job well. Problems that occur generally are employees whose job satisfaction is high but do not become employees with high productivity. Many opinions suggest that higher job satisfaction is mainly produced by work performance. Better work performance results in higher rewards. If the award is felt to be fair and adequate, then employee job satisfaction will increase because they receive awards in proportion to their work performance. Therefore, job satisfaction has an important meaning for employees and organizations, especially to create positive work for the organization.

Job satisfaction has long been an important and major predictor for employee performance (laffaldano and Muchinsky, 1985; Shore and Martin, 1989; Saari and Judge, 2004). Although some findings reveal the absence of the importance of satisfaction on employee performance (Hidayat and Ferdiansyah, 2011; Subakti, 2013; and Dinc and Plakalovic, 2016); in general generalization of results about the importance of job satisfaction in predicting employee performance has been widely recognized and reviewed in general in various studies (Hayati and Chaniago, 2012; Dhermawan et al., 2012; Rahayu, 2014). Based on this description and the empirical and theoretical study in the previous section, the fourth hypothesis proposed in this study is as follows:

H4: Job Satisfaction has an important effect to improve public officer performance

An employee who is committed to the organization will choose to stay, accept, and believe in the goals of the organization and provide the best effort to achieve these goals (Allen and Meyer, 1990). Committed employees will always strive to be able to give and do their best because they have positive feelings towards the organization (Orpen, 1997), where this is demonstrated through work effort which then improves the performance they display (Suliman and Iles, 2000).

In addition to job satisfaction, commitment is seen important in encouraging employee performance (Suliman and Iles, 2000; Suliman, 2002). The findings of previous studies support this premise by revealing that organizational commitment has an important effect on employee performance (Ranihusna, 2010; Susanty and Miradipta, 2013). The commitment and performance relationship were interpreted positively and significantly (Dharmanegara et.al., 2016; and Fabio, Hubeis, and Puspitawati, 2016). It means that the higher organizational commitment will improve employee performance. Based on this description and the empirical and theoretical studies in the previous section, the fifth hypothesis proposed in this study is as follows:

H5: Organizational Commitment has Important effect In Improving Employee Performance

\section{Methodology}

The object of research in this study is all civil servants within the scope of STIA (Institute of State Administration). In this study, the location of the study was located in the STIA (Institute of State Administration), which was in Jakarta, Bandung and Makassar. The estimation of the time of this research ranged from approximately two months, from May to June 2018. The process of collecting data was through questionnaires for civil servants within the scope of STIA as sample in the study. 
INTERNATIONAL JOURNAL OF ACADEMIC RESEARCH IN BUSINESS AND SOCIAL SCIENCES Vol. 8, No. 12, Dec, 2018, E-ISSN: 2222-6990 @ 2018 HRMARS

The data analysis method used is Partial Least Square (PLS) with the calculation process assisted by the SmartPLS software application program. Analysis with PLS is used because the model used in this study is quite complicated. PLS analysis has two models, namely the inner and the outer model. Outer model, which is also called the outer relation or measurement model, showed the specification of the relationship between variables and indicators. In other words, the outer model defines the characteristics of the construct with its manifest variables. While the inner model which is also called inner relation or structural model shows the specification of the relationship between hidden or latent variables, that is, between exogenous variables and endogenous variables (Ghozali, 2008).

\section{Result and Discussion}

Hypotheses testing was performed in PLS (Partial Least Square) analysis. The criteria in testing this hypothesis is $\mathrm{Ho}$ is rejected if the sig value is $<0.05$ (or the statistic value $>1.96$ or if the test has a significance level of 0.05 ).

Table 1.

Path Analysis

\begin{tabular}{|l|c|c|c|c|}
\hline \multicolumn{1}{|c|}{ Relationship Among Variables } & $\begin{array}{c}\text { Beta } \\
\text { Coefficient }\end{array}$ & t-statistic & Remarks & Remarks \\
\hline $\begin{array}{l}\text { Public Service Motivation -> } \\
\text { Organizational Commitment }\end{array}$ & 0.075 & 0.838 & $\begin{array}{c}\text { Not } \\
\text { Significant }\end{array}$ & H1 rejected \\
\hline $\begin{array}{l}\text { Job Satisfaction -> Organizational } \\
\text { Commitment }\end{array}$ & 0.648 & 7.754 & Significant & H2 accepted \\
\hline $\begin{array}{l}\text { Public Service Motivation -> Public } \\
\text { Officer Performance }\end{array}$ & 0.189 & 2.050 & Significant & H3 accepted \\
\hline $\begin{array}{l}\text { Job Satisfaction -> Public Officer } \\
\text { Performance }\end{array}$ & -0.058 & 0.485 & $\begin{array}{c}\text { Not } \\
\text { Significant }\end{array}$ & H4 rejected \\
\hline $\begin{array}{l}\text { Organizational Commitment -> Public } \\
\text { Officer Performance }\end{array}$ & 0.545 & 4.728 & S Significant & H5 accepted \\
\hline
\end{tabular}

Source : Result of primary data processed (2018)

As stated in Table 1 for the results of the path coefficient test, the t-statistic value that exceeds the critical value of 1.96 is stated to be significant and vice versa. Overall, the t-statistical value of the relationship between the two variables in Table 4 showed a significant relationship in each relationship between variables in this research model. This is evidenced by the t-statistical value of the two relations which is greater than the critical value of 1.96. In Figure 1 . It is shown the path diagram of the relationship between variables and their relationship weight values. 
Figure 1

Path Analysis after Hypothesis Testing

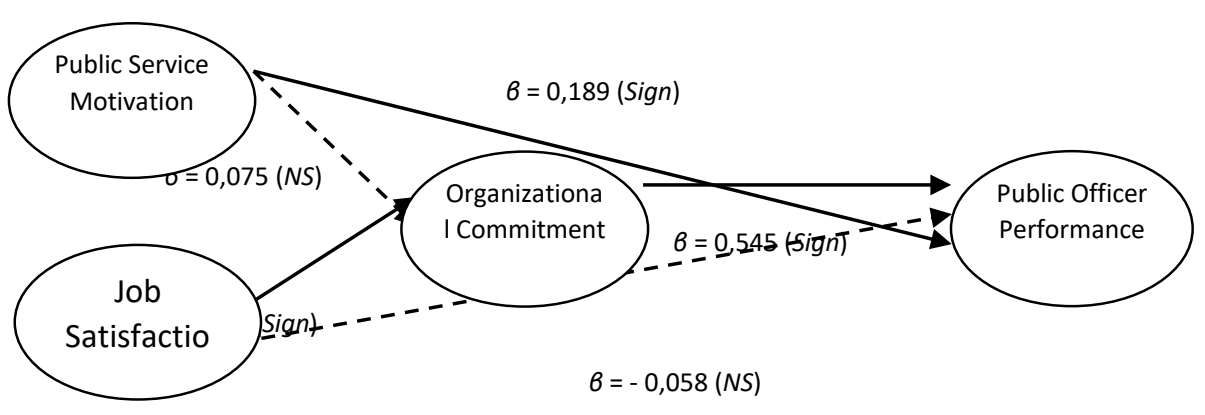

Resource : Result of data analysis with SmartPLS (2018)

Important results indicate that:

1. The average respondent's answer to the variables observed in this study (public service motivation, job satisfaction, organizational commitment and employee performance) ranged from 3.95 to 3.99. The range shown from the mean of the answer is very close. Although the mean of the answers shows a good level of answers, but the average range of these numbers implies that there is no good perception or feeling from the employees about public service motivation, job satisfaction, organizational commitment, and employee performance in STIA LAN. In addition, several important things that need to be conveyed include the following:

a. The lowest score is on job satisfaction, where the lowest indicator identified is about satisfaction with supervisors or superiors. This reflects that the pattern of relationship between superiors and subordinates has not run optimally so that it can support a positive feeling or affection from employees for their work.

b. The highest score is on employee performance. This condition shows that although it can be stated as not optimal, STIA LAN employees have tried to do their best in their work, especially in terms of the timeliness of completion of the work.

2. The largest loading coefficient value from the manifest variable observed in this study is an indicator of the organizational commitment construct that is an indicator of normative organizational commitment. The highest indicator is an indicator with the biggest weighting factor that reflects organizational commitment. The factor of weighting value is also the biggest factor weight value from other indicators observed in this study in reflecting their respective latent variables.

The test results of the outer model or measurement model for this study from all constructs of variables have met the criteria for discriminant and composite reliability. Employee performance becomes a construct that has the highest regular value compared to other constructs, while organizational commitment has the lowest regular value. This finding (the value of consistency for the commitment variable) is quite interesting when considering the object of research in public organizations. On the other hand, the measure of convergent validity in all constructs observed in this study has met the required criteria. The use of research instruments 
in different contexts and objects is assumed not to experience problems, especially related to internal consistency.

The results of the analysis show that not all of the characteristics on the pathway in the research model are found to be significant or important. Causality relationships were identified as important for each path effect for the relationship between variables observed in this study, except for the two hypothesized pathways previously, namely the path of the effect of public service motivation on organizational commitment and the effect of job satisfaction on employee performance. From all the relationships between variables in the research model, the greatest impact was found on the effect of job satisfaction on organizational commitment of STIA LAN Public servants. This finding is in line with previous empirical studies that review the close relationship between satisfaction and commitment.

Motivation of public services is found not to have an important impact on organizational commitment. Unlike the motivation of public services, job satisfaction is the most important thing that has a dominant effect on increasing a person's attachment to an organization. Motivation of public services and organizational commitment can be a good predictor of employee performance in STIA LAN. Satisfaction as a form of other attitudinal mechanisms beyond motivation and commitment was found not to have an important impact on improving employee performance at STIA LAN. When compared to the motivation of public services, commitment is more dominant in having important impact on improving employee performance. Therefore, STIA LAN employees who feel satisfied with their work must be encouraged to feel more attached to the STIA LAN organization in order to be able to improve the results of the work shown.

\section{Conclusion}

Motivation of public services that is more reflected by feelings of sympathy or compassion has an important impact in improving the performance of civil servants in the College of Administrative Sciences (STIA) which is more indicated by the timeliness of completion of work. Job satisfaction which is more reflected by satisfaction with the work itself does not have an important impact in improving the performance of civil servants in the College of Administrative Sciences which is more indicated by the timeliness of completion of the work. Organizational commitment that is more reflected by normative organizational commitment has an important effect in improving employee performance. Organizational commitment is the most important thing in improving the performance of Civil Servants in the College of Administrative Sciences. In addition, organizational commitment was found to play an important role in mediating the effects of job satisfaction on employee performance. Public service motivation that is more reflected by feelings of sympathy or compassion does not have an important effect in increasing organizational commitment reflected by the normative organizational commitment of Civil Servants in the College of Administrative Sciences. Job satisfaction reflected in the satisfaction of the work itself has an important effect in increasing organizational commitment as it was reflected by the normative organizational commitment of Civil Servants in the College of Administrative Sciences. Satisfaction is the most important thing in improving the organizational commitment of Civil Servants in the College of Administrative Sciences.

This study does not distinguish samples based on personal characteristics, including assessing the relationship with perceived personal perceptions of things other than those listed in the model. 
Because this study focuses more on examining the causality relationship between exogenous and endogenous variables in which its measurement instruments are developed from previous theoretical and empirical studies, this research only focuses on STIA Civil Servants as Institution of State Administration. Therefore, the results are limited to the scope of the research object. Results cannot be used to generalize results at a broader level. This research was only carried out at one time (cross-sectional study), meaning that the study was not longitudinal and did not consider different time duration. This study cannot compare the perception of the STIA LAN civil servant in a continuous time span, so that it can provide additional information about the phenomenon in the study.

1. For the ranks of leaders and managers in the College of Administrative Sciences, it is advisable to be able to:

a. Increase self-awareness of positive feelings (sympathy and compassion) in the Civil Servants as the most important thing in the minds of employees as a form of self-motivation to serve and prioritize the public interest.

b. Improve better and positive supervision patterns, so as to encourage better perception of employees about superiors. Conditions like this can encourage a feeling that employees which are supported by the organization will have a direct impact in the form of an increase in work done in return for the support received. Supervisors should not consider PSM change as a "one-size-fits-all" solution to manage public service behaviors but rather take into account the tenure of individual public service providers.

2. For researchers and further research, it is recommended to be able to:

a. Consider the broader scope of the research object to further enrich the results and findings of the study, in addition to testing the model in other more specific contexts, for example at the locus of objects of nonprofit research,

b. Consider to explore other aspects of factors that have or have not been examined in the research model, such as factors that can affect organizational commitment and employee performance in addition to motivation and job satisfaction. Similar research in the future is by modifying the research model and adding other concepts investigated in order to provide a more in-depth explanation of the patterns of linkages between attitudes (towards work, towards the organization) and the individual behavior that is formed (employee performance). The attitude-behavior model can be an informative study material for decision makers in an organization.

c. Consider using the longitudinal nature of subsequent research to reveal whether there are differences or not for the consistency of empirical results over time.

\section{Acknowledgment}

The authors of this article declare no conflict of interest. The authors are responsible for the content and writing of the paper.

\section{Corresponding Author \\ Ricky Adi Putranto}

School Of Administration, National Agency for State Administration, Bandung, Indonesia, J

Cimandiri 34 -38 Bandung 40115

Email: wowricky76@gmail.com 
INTERNATIONAL JOURNAL OF ACADEMIC RESEARCH IN BUSINESS AND SOCIAL SCIENCES

Vol. 8, No. 12, Dec, 2018, E-ISSN: 2222-6990 @ 2018 HRMARS

\section{References}

Ajzen, I. (2011).Job Satisfaction, Effort, and Performance: A Reasoned Action Perspective. Contemporary Economics Vol. 5 Issue 4, 32-43, 2011.

Akbar, R.D. (2014).Pengaruh Kemampuan, Motivasi dan Kepuasan Kerja Terhadap Kinerja Pegawai Negeri Sipil di Lingkungan Kecamatan Tambaksari Surabaya. Kebijakan dan Manajemen Publik, Volume 2, Nomor 1, pp. 1 - 10.

Allen, N.J., and Meyer J.P. (1990). The measurement and Antecedents of Affective, Continuance and Normative Commitment to The Organization, Journal of occupational Psychology. Vol.63., (1). pp.1-18.Alonso, P., \& Lewis, G.B. (2001). Public Service Motivation and Job Performance: Evidence from the Federal Sector. The American Review of Public Administration, 31: 363 380. DOI: $10.1177 / 02750740122064992$.

Belle, N. (2012). Experimental Evidence on the Relationship between Public Service Motivation and Job Performance.Public Administration Review, Vol. 73, Iss. 1, pp. 143-153. DOI: 10.111/j.1540-6210.2012.02621.x.

Camilleri, E., \& Heijden, B.I.J.M. (2007).Organizational Commitment, Public Service Motivation, and Performance Within the Public Sector. Public Performance \& Management Review, 31:2, 241274. DOI 10.2753/PMR1530-9576310205.

Cheng, Ki. (2015).Public service motivation and job performance in public utilities - An investigation in a Taiwan sample. International Journal of Public Sector Management, Vol. 28 No. 4/5, 2015 pp. 352-370. DOI 10.1108/IJPSM-08-2015-0152.

Christensen, R.K., \& Wright, B.E. (2011).The effects of public service motivation on job choice decisions: disentangling the contributions of person-organization fit and person-job fit. Journal of Public Administration Research \& Theory, Vol. 21, pp. 723-743.

Crewson, P.E. (1997). Public service motivation: building empirical evidence of incidence and effect. Journal of Public Administration Research and Theory, Vol. 7 No. 4, pp. 499-518.

Dharmanegara, I.B.A., Sitiari, N.W., Adelina, M.E.(2016).The Impact of Organizational Commitment, Motivation and Job Satisfaction on Civil Servant Job Performance in State Plantation Denpasar. IOSR Journal of Journal of Business and Management (IOSR-JBM), Vol.18, Issue 2, Ver II pp. $41-50$.

Dinc, M.S., Plakalovic, V.(2016).Impact of Caring Climate, Job Satisfaction, and Affective Commitment on Employees' Performance in the Banking Sector of Bosnia and Herzegovina. Eurasian Journal of Business and Economics, 2016, 9 (18), 1-16. Doi.org/10.17015/ejbe.2016.018.01.

Gagne, M., Deci, E.L. (2005). Self-determination theory and work motivation.Journal of Organizational Behavior, 26, 331-362. DOI: 10.1002/job.322.

Gondokusumo, S., Sutanto, E.M. (2015).Meningkatkan Komitmen dan Kepuasan untuk Menyurutkan Niat Keluar. Jurnal Manajemen dan Kewirausahaan, Vol. 17, No. 2, September 2015, 186-196 DOI: 10.9744/jmk.17.2.186-196.

Harlie, M. (2012).Pengaruh Disiplin Kerja, Motivasi dan Pengembangan Karier terhadap Kinerja Pegawai Negeri Sipil pada Pemerintah Kabupaten Tabalong di Tanjung Kalimantan Selatan. Jurnal Aplikasi Manajemen, Vol. 10, No. 14, pp. 860 - 867. 
INTERNATIONAL JOURNAL OF ACADEMIC RESEARCH IN BUSINESS AND SOCIAL SCIENCES Vol. 8, No. 12, Dec, 2018, E-ISSN: 2222-6990 @ 2018 HRMARS

Hayati, K. \& Chaniago, I. (2012). Islamic Work Ethic: The Role of Intrinsic Motivation, Job Satisfaction, Organizational Commitment and Job Performance. Procedia - Social and Behavioral Sciences (65), 272 - 277. doi: 10.1016/j.sbspro.2012.11.122.

Hidayat, C., Ferdiansyah. (2011). Pengaruh Motivasi dan Kepuasan Kerja Terhadap Kinerja. Binus Business Review Vol. 2, (1), pp. 379-386.

Jackson, P.M. (1993).Public service performance evaluation: A strategic perspective. Public Money \& Management, 13:4, 9-14. DOI: 10.1080/09540969309387783.

Komara, A.T., \& Nelliawati, E. (2014). Pengaruh Kompensasi, Motivasi dan Kepuasan Kerja Terhadap Kinerja Pegawai Negeri Sipil (PNS) di Lingkungan Rumah Sakit Umum Daerah (RSUD) Kota Bandung. Jurnal Ekonomi, Bisnis \& Entrepreneurship, Vol. 8, No. 2, Oktober 2014, 73-85.

Leisink, P., \& Steijn, B. (2009). Public service motivation and job performance of public sector employees in the Netherlands. International Review of Administrative Sciences, Vol 75(1):3552. DOI:10.1177/0020852308099505.

Mathieu, J. E, \& Zajac, D. M. (1990). A Review and Meta Analysis of The Antecedents, Correlates, and Consequences of Organizational Commitment. Psychological Bulletin, 108 (2): 171 - 194.

Mostafa, A.M.S., Gould-Williams, J.S., Bottomley, P.(2015).High-Performance Human Resource Practices and Employee Outcomes: The Mediating Role of Public Service Motivation. Public Administration Review, Vol. 75, Issue 5. DOI: 10.1111/puar.12354.

Mouloud, K., Bougherra, B., Samir, B.F. (2016). Job satisfaction for physical education teachers and its relationship to job performance and organizational commitment. Pedagogics, psychology, medical-biological problems of physical training and sports, Vol ;3:47-51. doi:10.15561/18189172.2016.0307.

Oktariani, D., Hubeis, A.V.S., Sukandar, D. (2017).Kepuasan Kerja Generasi X dan Generasi Y Terhadap Komitmen Kerja di Bank Mandiri Palembang. Jurnal Aplikasi Bisnis dan Manajemen, Vol. 3 No. 1, Januari 2017. DOI: 10.17358/JABM.3.1.12.

Orpen, C. (1997).The effects of formal mentoring on employee work motivation, organizational commitment and job performance.The Learning Organization, Vol. 4, No. 2, pp. 53-60.

Ostroff, C. (1992). The relationship between satisfaction, attitudes, and performance: an organizational level analysis. Journal Of Applied Psychology (JAP) 77, 963 - 74.

Perry, J. L., \& Wise, L. R. (1990). The motivational bases of public service. Public Administration Review, 50(3), 367-373.

Potipiroon, W., \& Ford, M.T. (2017). Does Public Service Motivation Always Lead to Organizational Commitment? Examining the Moderating Roles of Intrinsic Motivation and Ethical Leadership.Public Personnel Management, 1- 28. DOI:10.1177/0091026017717241.

Rahayu, L. (2014). Pengaruh Motivasi dan Kepuasan Kerja Terhadap Kinerja Guru di SMP Negri 5 Magelang. Economic Education Analysis Journal Vol 3 (3), pp. 544 - 550.

Rajagukguk, P. (2016). Pengaruh Motivasi dan Komitmen Organisasi Terhadap Kinerja Pegawai (Study pada PT Challenger Tanggerang). Ecodemica, Vol. IV No.1 April 2016, pp. 23 - 31.

Ranihusna, D. (2010). Efek Rantai Motivasi Pada Kinerja Karyawan. Jurnal Dinamika manajemen Vol. 1, No. 2, 2010, pp: 90-103.

Riketta, M. (2002). Attitudinal organizational commitment and job performance: A meta-analysis. Journal of Organizational Behavior, 23 (3), 257-266. 
INTERNATIONAL JOURNAL OF ACADEMIC RESEARCH IN BUSINESS AND SOCIAL SCIENCES

Vol. 8, No. 12, Dec, 2018, E-ISSN: 2222-6990 C 2018 HRMARS

Robbins, S.P, \& Judge, T.A. (2008). Perilaku Organisasi. Jakarta: Salemba Empat.

Saari, L.M., \& Judge, T.A. (2004). Employee Attitudes and Job Satisfaction. Wiley Periodicals, Inc. : Human Resource Management, Winter 2004, Vol. 43, No. 4, Pp. 395-407.

Shore, L.M., and Martin, H.J.(1989).Job Satisfaction and Organizational Commitment in Relation to Work Performance and Turnover Intentions. Human Relations, Vol. 42 No. 7, pp. $625-638$.

Sonnentag, S, \& Frese, M. (2002). Performance Concepts and Performance Theory. Psychological Management of Individual Performance. John Wiley \& Sons, Ltd.

Subakti, A.G. (2013). Pengaruh Motivasi, Kepuasan, dan Sikap Kerja Terhadap Kinerja Karyawan di Cafe X Bogor. Binus Business Review Vol. 4, No. 2 November 2013: pp. 596-606.

Suliman, A.M.T. (2002). Is it really mediating construct? The Mediating Role of Organizational Commitment in Work Climate - Performance Relationship. Journal of Management Development, Vol.21 No.3, pp. 170-183.

Suliman, A., Iles, P. (2000). Is continuance commitment beneficial to organizations? Commitmentperformance relationship: a new look. Journal of Managerial Psychology, Vol. 15 No. 5, pp. 407-426. Viswesvaran, Chockalingam. (2001). Assessment of Individual Job Performance: A Review of the Past Century and a Look Ahead. In Handbook of Industrial, Work \& Organizational Psychology Volume 1 : Personnel Psychology. Sage Publications.

Susanty, A.; Miradipta, R.(2013).Employee's Job Performance: The Effect of Attitude toward Works, Organizational Commitment, and Job Satisfaction. Jurnal Teknik Industri, Vol. 15, No. 1, Juni 2013, pp. 13-24. DOI: 10.9744/jti.15.1.13-24.

Suwardi, \& Utomo, J. (2011).Pengaruh Motivasi Kerja, Kepuasan Kerja, dan Komitmen Organisasional Terhadap Kinerja Pegawai (Studi Pada Pegawai Setda Kabupaten Pati). Analisis Manajemen Vol. 5 No. 1 Juli 2011.

Taylor, J. (2008).Organizational Influences, Public Service Motivation and Work Outcomes: An Australian Study. International Public Management Journal, 11:1, 67-88, DOI:10.1080/10967490801887921.

Yucel, I., Cetin, B. (2012). Job satisfaction, organizational commitment and demographic characteristics among teachers in Turkey: Younger is better?. Procedia-Social and Behavioral Sciences Vol. 46, pp. 1598 - 1608. DOI: 10.1016/j.sbspro.2012.05.346. 